\title{
The Library in the Modern World
}

$\mathrm{T}$

HERE IS A GOOD REASON why the dedication of this library should excite the imagination and quicken the pulse. The reason is that this affair involves the heart of the university and affairs of the heart are always exciting.

It is important to emphasize that what I have said about this library is not universally true. I wish it were. Some libraries are not at the heart of their universities, and both the university and the library are the losers. But this library has been conceived and built with one central purpose - to be the center of the intellectual energy and life of the entire university. It is this concept that makes this library important. It is this concept that gives this dedication a special claim on our affections and our pride.

In taking its vow to honor, cherish, and support its library, Colgate also does honor to one of the oldest traditions of scholarship. There was a time, indeed, when a library was considered the greatest of all national treasures. We can remind ourselves that Demetrius Phalereus, who superintended the great library at Alexandria, held up a large shipment of supplies to Greece-not because he wanted more money but because he insisted that Egypt be paid by Greece in original manuscripts for the Alexandrian library. Phalereus held out for two folios by Aeschylus, one by Sophocles, and one by Euripides. Not even a lefthander or a switch-hitter to seal the bargain. Just a straight transaction of

Mr. Cousins is Editor, Saturday Review. This is the text of a talk given at the dedication of the new library building at Colgate University, A pril 13, 1959. several dozen tons of wheat for a few pounds of manuscript.

And the importance attached to libraries in those early but otherwise advanced times may be apparent from the amount of time Cicero took away from his consulship to spend in the library. Every now and then, in fact, it became necessary for Cicero to assure the people that he was not neglecting affairs of state in the pursuit of his hobby. In more recent times, this question has come up in a somewhat different form, indicating that the distance from Publicans to Republicans may not be as great as we think.

In any event, the Greeks and the Romans had a word for their books, a good word, and they attached to their libraries the same special feelings of satisfaction and awe that a more modern generation has sometimes applied to Fort Knox. Indeed, the Latin term thesaurus means, quite literally, a treasurehouse. A library was a state treasure. In any inventory of their national assets, the Romans counted their manuscripts even before they counted their edifices.

To be sure, a library in the old days was rather careful about the company it kept. The first question a Roman interested in a library would ask was not "How many books does it have?" or even "What did it cost?" but "What does it have that is worth providing space to keep?" The yardstick then and for a few centuries to come was not coverage so much as it was cogency. As late as the fourteenth century, in fact, one of the best libraries in Europe, the Royal Library of France, did not number more than nine hundred volumes, all of which knew the meaning of full-time 
service. And some of the finest libraries in London proclaimed their superiority over the French because they carried even fewer volumes.

In our time, of course, we are compelled to be comprehensive. Inevitably so. New knowledge is just as much entitled to elbow room as the old. In fact, new knowledge is being generated so fast that it can hardly be classified let alone be fitted out for its cubicles. We must manage somehow both to pay our respects to such new knowledge and to find a place for it on the open stacks.

Even so, one wonders whether the fascination with numbers ought not to be subdued somewhat where books are concerned. The value of a library is no more represented by the number of volumes it houses than a book by the number of its pages. It is what happens to people inside the library that counts and not the yardage of the catalog cards. A good library should be the delivery room of the intellect for people who like to bring ideas to life. It is also, or should be, a busy thoroughfare where a reasonably curious man can rub shoulders with the interesting and provocative people of history, and, indeed, where he can get on reading terms with some original ideas. It is an exchange center for basic facts, to be sure; but there is no reason why it should not also fulfill Disraeli's designation as a place which affords the consoling pleasures of the imagination. Finally, however, a library is the headquarters for the endless process of education and learning. It is a diffusion center for the intellectual energy in the vital life of the mind. It is a seminal center for change.

Our concern as a people today is with change-with the challenge of change in a modern world.

Whether the idea of America survives in this world may depend less upon the amount of destructive force we can develop or use than upon our ability to deal with the problem of change in our time.

There is not a single critical situation in the world today that does not involve the challenge of change. It makes little difference whether we are talking about our relations with the rest of the world, our economy, our education, or even our hopes. There is a fast-moving current of change that ties all our problems together. They are tied together in the sense that all of them make insistent demands on us: either we understand the vital problem of change involved in each case or we are left on a historical siding while the rest of the world goes billowing by.

There was a time in the life of nations and civilizations when the pace of change was glacial. The problems of the period of the Enlightenment, for example, were at least two hundred years in the making. The effects were spread out over another century or more. The lifeblood of Greece may have run out in large measure during the Peloponnesian Wars, but the causes fed slowly into that conflict and the consequences distributed their hurt over long years. In fact, ours is the first generation in history that has had to absorb the kind of changes that heretofore took thousands of years to produce.

From 1945 to 1959 we have had to withstand and comprehend greater and more fundamental changes than have been recorded in all the histories since man first began to record his histories. In less than fifteen years we have seen change overtake almost the entire body of science and systematic knowledge. The one event represented by the liberation of atomic energy may have greater significance than any previous utilization of the scientific intelligence of man. The conquest of earth gravity, as represented by the man-made satellite, may have an even more profound effect on philosophy than upon physics. A sudden 
new perspective bursts upon the mind. The human brain now begins to perceive, however dimly, the meaning of a universe in which the earth and, indeed, the solar system may occupy a position in relationship to the whole no larger than the atom itself is to this planet.

Nothing has been more difficult in the evolution of thought than for man to depart from his view of himself as central in the universe. But now we have to begin to live with the idea that life, life with intelligence, may exist on millions or billions of planets and may even, in many cases, be far superior to our own.

Meanwhile, even as we prepare to take off for other worlds we seem to be doing our level best to get rid of this one. The means now exist and stand primed for instant use-means that can expunge in a few seconds the work and culture of man that required thousands of years to put together piece by piece. No one knows whether it took man a quarter of a million years to evolve into his present being, or a half million years, or two million years. What we do know is that he has now employed his evolved intelligence in the creation of explosives that would put an end to his place on this earth at least.

Whether the explosives go off or whether this planet becomes a safe place for human life depends not on magical solutions but on the ability of man to understand the challenge of change.

If the use of nuclear military force no longer can achieve victory but achieves the finality of suicide, then it becomes important to understand this change and attempt to devise those means that can be effective in enabling us to preserve our freedom and values and also serve the cause of humankind in general.

If our security today no longer depends on the pursuit of force but on the control of force in the world, then it becomes necessary to understand this change and make the kind of connec- tions with the rest of the world that gives us the basis for genuine leadership in that direction.

If we are challenged by a powerful ideology, we can recognize that the only time we need fear an ideology is if we lack a great idea of our own-an idea that is great enough to encompass change, great enough to unify man, and set him free, give him reasonable peace, and make the world safe for his diversity.

The great idea is clearly within our reach. The uniqueness of the human mind is precisely that it is potentially capable both of recognizing the fact of change and devising the means for meeting it.

A library not only records change; it scrutinizes change, perceives its germinal characteristics, contemplates its effects, and meditates on the failures to comprehend it.

In sum, the library offers more than incidental intelligence today for a society looking for a place to go. One of the unhappy aspects of our age is that we live largely in a state of historical disconnection. We have not really put our experience to work in coping with new dangers. We have tended to segregate ourselves from the wisdom accumulated over long centuries-wisdom that deals with principles that can be put to work in the operation of a complex civilization. We have made the mistake of thinking that because there is so much that is new in the nature of contemporary crisis that the past has nothing of value to say to us. But the fact that men like Socrates or Comenius or Milton or Jefferson or Lao-Tse or Confucius or Tagore did not have to cope with atomic weapons or intercontinental missiles does not mean that their views of life and great issues had meaning only for their own times.

Similarly, the Peloponnesian Wars may be more than two thousand years in the past, but some of the basic prin- 
ciples emerging from that experience might be helpful today. And the story of man's own growth and his struggle to create and preserve his noble worksall this deserves our historical respect. At least we ought to know what it is that is now being jeopardized.

In this sense, I repeat, that the library may be able to speak to the human conditions in today's world. For books serve as the natural bloodstream of human experience. They make it possible for the big thoughts of big minds to circulate in the body of history. They represent a point of contact between past and future. There is something else that books can do. They can help in the conversion skills that mankind now requires. For it is not enough that man can convert so beautifully in the fields of science and technology.

It is not enough for man to convert the face of nature into a countenance congenial to human life. He can convert sand, stone, and water into gleaming and wondrous towers. Not enough to convert fluids into fabrics. Not enough to convert the invisible atom into an infinity of power. Not enough to convert the rush of water into the whirling fantasy of the dynamo and thence into the magic impulses that banish darkness or turn wheels or carry images and voices over empty space. Not enough, even, to convert air, agitated by the spin of a blade or the thrust of a jet, into the lifting power that enables him to rise from the earth and fly over the mountains and the seas.

What is most needed now by man is to apply his conversion skills to those things that are most essential for his survival. His urgent and overriding need is to convert facts into logic, free will into purpose, conscience into decision. $\mathrm{He}$ has to convert historical experience into a design for a sane world. $\mathrm{He}$ has to convert the vast processes of education into those ideas that can make this globe safe for the human diversity. And he will have to learn more than he knows now about converting the individual morality into a group ethic.

Our failure to develop these conversion skills has converted us into paupers. The plenty produced by our scientific and physical skills has not relieved the poverty of our purposes. The only thing greater than our power is our insecurity. All our resources and all our wealth are not enough to protect us against the effects of irrational ideas and acts on the world stage. It makes little difference how magnificent are our new buildings or how impressive are our private kingdoms. If no answer is found to war, all men will die poor.

The library-and the term is used here as symbolic of the universe of knowledge, systematic and unsystematic both-the library can be a strong part of the new conversion process. It can furnish the basic materials that must go into the making of the new purposes and designs. And, quite possibly, it may furnish some of the motive power for the decision behind the effort itself.

Now some people may take the fatalistic view and say it is too late. They may say that man cannot possibly develop the comprehension necessary to deal with change in the modern world, that he will require many centuries before his conversion skills can be developed as they now need to be developed in the cause of human survival.

But there is a larger view of manone that history is prepared to endorse. This view holds that the great responses already exist inside man and that they need only to be invoked to become manifest. For man is infinitely malleable, infinitely perfectable, infinitely capacious. It is the privilege of anyone in a position of leadership to appeal to these towering possibilities.

By leadership I am not thinking of government alone. I am thinking of all those who work on the frontier of ideas. 
Leadership begins with ideas. And ideas, if they are big enough, can unfreeze man and make him relevant and effective in turning back the largest threat he has ever known.

It is self-evident that neither education nor the library which is at its heart can undertake the total function of leadership in our time. But the job will certainly not be done without education. In dedicating this library, therefore, we also dedicate ourselves to the need for great conversions, to the need for a seed-bed of change.

\section{Doctoral Study for Librarianship}

(Continued from page 453)

Study of the Effect of Differences in Research Method." Illinois, 1951.

Stieg, Lewis Francis. "An Introduction to Paleography for Librarians." Chicago, 1935.

Stokes, Katharine M. "Book Resources for Teacher Education: A Study Toward the Compilation of a Core List." Michigan, 1959.

Stone, John Paul. "Regional Union Catalogs: A Study of Services Actual and Potential." Chicago, 1945.

Swank, Raynard Coe. "The Organization of Library Materials for Research in English Literature." Chicago, 1944.

TaAM, Cheuk-Woon. "The Development of Chinese Libraries Under the Ch'ing Dynasty, 1644-1911." Chicago, 1933.

Tauber, Maurice Falcolm. "Reclassification and Recataloging in College and University Libraries." Chicago, 1941.

Tracy, Warren Francis. "Public Library and the Courts." Chicago, 1958.

Tsien, Tsuen-Hsuin. "The Pre-Printing Records of China: A Study of the Development of Early Chinese Inscriptions and Books." Chicago, 1957.

Upton, Eleanor Stuart. "A Guide to Sources of Seventeenth-Century English History in Selected Reports of the Royal Commission on Historical Manuscripts." Chicago, 1930.

Van Hoesen, Florence Ruth. "Analysis of Adult Reference Work in Public Libraries as an Approach to the Content of a Reference Course." Chicago, 1948.

Van Male, John Edward. “The State as Li- brarian: A Study of the Co-ordination of Library Services in Wisconsin." Chicago, 1942.

VANN, Sarah Katherine. "Education for Li- brarianship, Dewey to Williamson, 18871923." Chicago, 1959.

Vert, Fritz. "State Supervision of Public Libraries: With Special Emphasis on the Organization and Functions of State Library Extension Agencies." Chicago, 1941.

Villalon, Alberto. "An Introduction to Latin American Juridical Bibliography." Michigan, 1959.

Wellard, James Howard. "Bases for a Theory of Book Selection.” Chicago, 1935.

Williams, DoRothy Gwendolyn. "Treatment of the Second Roosevelt Administration in Three Popular Magazines." Chicago, 1947.

Willoughby, Edwin Eliott. "The Printing of the First Folio of Shakespeare." Chicago, 1932.

Winger, Howard WoOdrow. "Regulations Relating to the Book Trade in London From 1357 to 1586." Illinois, 1953.

Wu, Kwang Tsing. "Scholarship, Book Production, and Libraries in China (6181644)." Chicago, 1944.

Yenawine, Wayne Stewart. "The Influence of Scholars on Research Library Development at the University of Illinois." Illinois, 1955.

Zimmerman, Irene. "Latin American Periodicals of the Mid-Twentieth Century as Source Material for Research in the $\mathrm{Hu}$ manities and the Social Sciences." Michigan, 1956. 